\title{
Bridging gaps in the molecular phylogeny of the Lymnaeidae (Gastropoda: Pulmonata), vectors of Fascioliasis
}

\author{
Ana C Correa1*, Juan S Escobar², Patrick Durand' ${ }^{1}$, François Renaud ${ }^{1}$, Patrice David ${ }^{3}$, Philippe Jarne ${ }^{3}$, \\ Jean-Pierre Pointier ${ }^{4}$, Sylvie Hurtrez-Boussès ${ }^{1,5}$
}

\begin{abstract}
Background: Lymnaeidae snails play a prominent role in the transmission of helminths, mainly trematodes of medical and veterinary importance (e.g., Fasciola liver flukes). As this family exhibits a great diversity in shell morphology but extremely homogeneous anatomical traits, the systematics of Lymnaeidae has long been controversial. Using the most complete dataset to date, we examined phylogenetic relationships among 50 taxa of this family using a supermatrix approach (concatenation of the 16 S, ITS-1 and ITS-2 genes, representing 5054 base pairs) involving both Maximum Likelihood and Bayesian Inference.

Results: Our phylogenetic analysis demonstrates the existence of three deep clades of Lymnaeidae representing the main geographic origin of species (America, Eurasia and the Indo-Pacific region). This phylogeny allowed us to discuss on potential biological invasions and map important characters, such as, the susceptibility to infection by Fasciola hepatica and F. gigantica, and the haploid number of chromosomes (n). We found that intermediate hosts of F. gigantica cluster within one deep clade, while intermediate hosts of $F$. hepatica are widely spread across the phylogeny. In addition, chromosome number seems to have evolved from $n=18$ to $n=17$ and $n=16$.

Conclusion: Our study contributes to deepen our understanding of Lymnaeidae phylogeny by both sampling at worldwide scale and combining information from various genes (supermatrix approach). This phylogeny provides insights into the evolutionary relationships among genera and species and demonstrates that the nomenclature of most genera in the Lymnaeidae does not reflect evolutionary relationships. This study highlights the importance of performing basic studies in systematics to guide epidemiological control programs.
\end{abstract}

\section{Background}

Basommatophora (Gastropoda: Pulmonata) is a suborder comprising essentially all pulmonate gastropods living in freshwater. Basommatophorans are monophyletic and encompass five families: Acroloxidae, Chilinidae, Lymnaeidae, Physidae, and Planorbidae (including the Ancylidae) [1]. The group contains $\sim 300$ species and has been extensively studied because some species have a role in transmitting parasites of human and veterinary importance (e.g., Schistosoma and Fasciola). The Lymnaeidae, Physidae and Planorbidae comprise $\sim 90 \%$ of

\footnotetext{
* Correspondence: ac.correayepes@gmail.com

'Laboratoire Génétique et Evolution des Maladies Infectieuses, UMR 2724 CNRS-IRD, IRD 911 avenue Agropolis, BP64501, 34394 Montpellier Cedex 5, France

Full list of author information is available at the end of the article
}

the Basommatophoran species [1,2]. The phylogenetic relationships within the Physidae and Planorbidae are now well established (e.g., [3-5]). However, the phylogeny of the Lymnaeidae has only been partially inferred [6-11] and we currently lack a comprehensive treatment of this family.

Lymnaeidae snails are distributed worldwide [12-14]. They are of major medical and veterinary importance since they act as vectors of parasites that severely affect human populations and livestock, and cause important economic losses $[15,16]$. Indeed, lymnaeids serve as intermediate hosts of at least 71 trematode species distributed among 13 families $[17,18]$, including some species of Schistosomatidae and Echinostomatidae, with implications for human health $[19,20]$, and Paramphistomum daubneyi, which is of veterinary interest [21].
C Biomed Central

C 2010 Correa et al; licensee BioMed Central Ltd. This is an Open Access article distributed under the terms of the Creative Commons Attribution License (http://creativecommons.org/licenses/by/2.0), which permits unrestricted use, distribution, and reproduction in any medium, provided the original work is properly cited. 
Undoubtedly, the most emblematic case of parasite transmitted by lymnaeids is Fasciola hepatica (Digenea: Fasciolidae), the agent of fascioliasis. The disease it causes is recognized as a major veterinary problem as it is responsible of the loss of productive capacity (e.g., meat, milk). Fascioliasis is also an important human disease with about 20 million cases around the world [22]. Fasciola hepatica presumably originates from Europe and now has a worldwide distribution. The definitive hosts of this parasite are vertebrates, usually mammals, e.g., cows, sheep, goats, buffalos, and also humans. Mollusks, generally lymnaeids, are required as intermediate hosts to complete the life cycle. At least 20 species of Lymnaeidae have been described as potential vectors of fascioliasis (see reviews in $[17,23,24])$. Due to the important role of these species as intermediate hosts of trematodes, a solid phylogenetic framework of Lymnaeidae is required. The correct identification of intermediate-host species should help characterize areas of epidemiological risk and increase our understanding of the evolution of the Lymnaeidae- Fasciola host-parasite interaction.

Lymnaeidae exhibit a great diversity in shell morphology which is linked to substantial eco-phenotypic plasticity (see e.g., [25,26]). Hubendick [12] illustrated this point by compiling up to 1143 species names, a large number of which he synonymized. In contrast, the anatomy of their reproductive tracts (including prostate, penis and preputium) is extremely homogeneous (e.g., $[1,27,28])$. Immunological [29], cytogenetical [30,31], enzyme electrophoresis studies [25,32,33], and DNAbased approaches $[7,10]$ have demonstrated extensive homoplasy in anatomical characters [12,26,34-38]. The difference between patterns in shell morphology and anatomy explains why lymnaeid systematics has been controversial [6]. Today, it is accepted that the total number of species might be less than 100 [1], with most occurring in the Palearctic and Nearctic regions [2]. Although some effort has been done to resolve their phylogenetic relationships, the small number of genes or species considered (e.g., a single gene in [7]) and limited geographical coverage (e.g., Neotropic in [10], Australasia in [11] and ancient European lakes in [39]) represent severe limitations and biases. Furthermore, some wellrecognized species have never been considered (e.g., the Neotropical species Lymnaea cousini and $L$. diaphana). These limitations and biases have generated gaps in our understanding of their biogeographic patterns, and their epidemiology in areas of high endemicity of trematode diseases (e.g., South America; [40]).

In this paper, we contribute to fill these gaps by performing a phylogenetic analysis using a supermatrix approach. We infer the most complete phylogeny to date in Lymnaeidae using sequences of 50 taxa (i.e., approximately half of the supposed diversity of the family) covering most Neotropical species (including the unstudied L. diaphana, L. cousini and Lymnaea sp. from Colombia). Using this phylogenetic framework, we analyze how susceptibility to infection by $F$. hepatica and $F$. gigantica (the sister-species of $F$. hepatica mainly responsible for fascioliasis in Asia and Africa) has evolved. In addition, this phylogeny allows us to establish biogeographic aspects, to pinpoint potential biological invasions, and determine the evolution of chromosome numbers.

\section{Methods}

\section{Sampling}

Sequences of one to three genes among the two nuclear internal transcribed spacers of the ribosomal DNA (ITS1 and ITS-2) and the mitochondrial $16 \mathrm{~S}$ ribosomal DNA of 38 lymnaeid species and two outgroups, the planorbids Bulinus forskalii and Biomphalaria tenagophila (Planorbidae), were retrieved from GenBank (Table 1). We chose these three genes because they are highly variable and have been extensively used in phylogenetic studies of Lymnaeidae. They represent most known clades of this family (e.g., [6,7,9-11,41]). In addition, living individuals of 12 lymnaeid species and an additional outgroup, Physa acuta (Physidae), were collected in 13 populations sampled in a variety of countries/continents (Table 1). Sampled individuals were stored in $80 \%$ ethanol for DNA analyses.

Genus names are still fluctuating in Lymnaeidae. However, we conserved the names given in GenBank for the sequences retrieved there in order to facilitate comparisons between this and previous studies. For the species we sampled, we adopted the widely accepted genus Lymnaea for all species, except for Galba truncatula, Omphiscola glabra, Pseudosuccinea columella and Radix peregra (see Table 1).

\section{DNA Extraction and Polymerase Chain Reaction (PCR) Amplification}

Total DNA was isolated from the distal part of the foot. We carefully controlled for trematode presence during dissection in order to avoid exogen DNA. Extractions were performed using the DNeasy Blood and Tissue Kit (Qiagen) according to manufacturers' instructions. The two nuclear internal transcribed spacers (ITS-1 and ITS-2) and the $16 \mathrm{~S}$ gene were amplified using published primers [6,42] (Table 2). PCR amplification was performed for each pair of primers in a total volume of $25 \mu \mathrm{l}$ containing $5 \mu \mathrm{l}$ of PCR reaction buffer $5 \times, 2.5$ $\mathrm{mM} \mathrm{MgCl} 2,200 \mu \mathrm{M}$ of each dNTP, 10 pmol of each primer, $1 \mathrm{U}$ GoTaq DNA polymerase (Promega), and 2 $\mu \mathrm{l}$ of DNA template. Temperature cycling for the ITS-1 and ITS- 2 was as follows: $94^{\circ} \mathrm{C}$ for $2 \mathrm{~min}, 94^{\circ} \mathrm{C}$ for 30 sec, $50^{\circ} \mathrm{C}$ for $30 \mathrm{sec}, 72^{\circ} \mathrm{C}$ for $30 \mathrm{sec}$, repeated for 30 
Table 1 Names and accession numbers given in GenBank for the species used in the phylogeny presented in figure 1

\begin{tabular}{|c|c|c|c|c|}
\hline Species & Country, locality & ITS-1 & ITS-2 & $16 \mathrm{~S}$ \\
\hline Autropeplea lessoni & Australia & NA & EU556308 & EU556266 \\
\hline Autropeplea ollula & Philippines & NA & NA & U82067 \\
\hline Autropeplea tomentosa & Australia, Guyra & NA & EU556270 & AF485645 \\
\hline Autropeplea viridis (= Lymnaea viridis) & Australia, Perth (Queensland) & NA & EU556313 & AF485642 \\
\hline Biomphalaria tenagophila & Brazil, Rio Grande do Sul, Goias & AY425730 & AF198655 & AY030220 \\
\hline Bulimnea megasoma & Canada, Manitoba & NA & NA & U82069 \\
\hline Bulinus forskalii & Tanzania, Mafia Island, Angola, Quifangondo & AF503573 & AM921961 & AY029550 \\
\hline Bullastra cumingiana & Philippines, Luzon & NA & EU556314 & U82068 \\
\hline Fossaria bulimoides & USA, Oklahoma & NA & NA & AF485657 \\
\hline Fossaria obrussa & Canada, Ontario & NA & NA & AF485658 \\
\hline Galba truncatula & France, Limoges & HQ283251 & HQ283262 & HQ283236 \\
\hline Kutikina hispida & Australia, Franklin River & NA & EU556311 & EU556268 \\
\hline Lymnaea corvus & Austria, Wallersee; & NA & AJ319625 & U82079 \\
\hline (= Stagnicola corvus) & Bulgaria & & & \\
\hline Lymnaea cousini & Venezuela, Mucubají & HQ283255 & HQ283266 & HQ283237 \\
\hline Lymnaea cubensis & Colombia, Antioquia & HQ283253 & HQ283264 & FN182204 \\
\hline \multicolumn{5}{|l|}{ (= Bakerilymnaea cubensis) } \\
\hline Lymnaea diaphana & Argentina, Lago Escondido & HQ283256 & HQ283260 & HQ283241 \\
\hline Lymnaea fuscus & Germany, Westfallen & AJ626855 & AJ319622 & NA \\
\hline Lymnaea gen. sp. & Hawaii, Kauai & NA & NA & U82070 \\
\hline Lymnaea humilis & USA, Charleston (South Carolina) & FN182193 & FN182191 & FN182195 \\
\hline Lymnaea (Radix) natalensis & La Réunion, Bras de Pontho & HQ283257 & HQ283270 & HQ283242 \\
\hline Lymnaea neotropica & Peru, Lima & AM412228 & AM412225 & NA \\
\hline Lymnaea occulta & Poland & AJ626858 & AJ457042 & NA \\
\hline \multicolumn{5}{|l|}{ (= Catascopia occulta) } \\
\hline Lymnaea palustris & Sweden, Umea; & HQ283250 & HQ283267 & U82082 \\
\hline (= Stagnicola palustris) & Germany & & & \\
\hline Radix peregra & France, Viols le Fort (Herault); Turkey, Söke & HQ283258 & HQ283271 & U82074 \\
\hline Lymnaea sp. EEAR-China-2002 & China, Wuhan & NA & NA & AF485643 \\
\hline Lymnaea sp. Colombia & Colombia, Antioquia & HQ283252 & HQ283263 & HQ283235 \\
\hline Lymnaea sp. EEAR-Hawaii-2002 & USA, Hawaii & NA & NA & AF485644 \\
\hline Lymnaea stagnalis & France, Lacépede (Lot et Garonne); Canada & NA & HQ283268 & AF485659 \\
\hline Stagnicola turricola & Austria, Wallersee & AJ626853 & AJ319618 & NA \\
\hline \multicolumn{5}{|l|}{ (= Lymnaea palustris turricola) } \\
\hline Lymnaea viatrix & Argentina, Rio Negro & HQ283254 & HQ283265 & HQ283239 \\
\hline Omphiscola glabra & France, Limoges & HQ283249 & HQ283269 & HQ283246 \\
\hline Physa acuta & Mexico, Veracruz & HQ283259 & HQ283272 & GQ415021 \\
\hline Pseudosuccinea columella & Colombia, Antioquia; Australia & HQ283248 & HQ283261 & U82073 \\
\hline Radix ampla & Austria, Wallersee & NA & AJ319640 & NA \\
\hline Radix auricularia & Czech Republic; Danube Delta, Romania & NA & AJ319628 & AF485646 \\
\hline Radix labiata & Czech Republic; Turkey & NA & AJ319636 & NA \\
\hline Radix lagotis & Austria, Schönau & NA & AJ319639 & NA \\
\hline Radix luteola & Sri Lanka & NA & NA & AF485648 \\
\hline Radix ovata & Germany, Tubingen & NA & NA & AF485647 \\
\hline Radix quadrasi & Philippines, Luzon & NA & EU556315 & U82075 \\
\hline Radix rubiginosa & West Java; Malaysia & NA & EU556316 & U82076 \\
\hline Radix sp. EEAR-Canada-2002 & Canada, Manitoba & NA & NA & AF485650 \\
\hline Radix sp. EEAR-Philippines-2002 & Philippines, Taal Lake & NA & NA & AF485649 \\
\hline Radix sp. EEAR-Romania-2002 & Romania, Razelm Lake & NA & NA & AF485651 \\
\hline Stagnicola bonnevillensis & USA, Utah & NA & NA & AF485655 \\
\hline Stagnicola caperata & Canada, Manitoba & AF013140 & AF013140 & U82077 \\
\hline
\end{tabular}


Table 1 Names and accession numbers given in GenBank for the species used in the phylogeny presented in figure 1 (Continued)

\begin{tabular}{|c|c|c|c|c|}
\hline Stagnicola catascopium & USA, Au Sable River (Michigan) & AF013143 & AF013143 & U82078 \\
\hline Stagnicola elodes & USA, Michigan; Canada, Ontario & AF013138 & AF013138 & AF485652 \\
\hline Stagnicola elrodi & USA, Montana & NA & NA & AF485656 \\
\hline Stagnicola emarginata & USA, Higgins Lake (Michigan) & AF013142 & AF013142 & U82081 \\
\hline Stagnicola sp. EEAR-Manitoba-2002 & Canada, Manitoba & NA & NA & AF485653 \\
\hline Stagnicola sp. EEAR-Montana-2002 & USA, Montana & NA & NA & AF485654 \\
\hline Stagnicola sp. EEAR-Ukraine-2002 & Ukraine, Sasyk Lake & NA & NA & AF485662 \\
\hline
\end{tabular}

Species in bold characters were sampled by us. NA: not available.

cycles, and final extension at $72^{\circ} \mathrm{C}$ for $7 \mathrm{~min}$. Temperature cycling for the $16 \mathrm{~S}$ gene was $95^{\circ} \mathrm{C}$ for $3 \mathrm{~min}, 50^{\circ} \mathrm{C}$ for $2 \mathrm{~min}, 72^{\circ} \mathrm{C}$ for $1.5 \mathrm{~min}$, four times at $93^{\circ} \mathrm{C}$ for 15 sec, $50^{\circ} \mathrm{C}$ for $8 \mathrm{sec}, 72^{\circ} \mathrm{C}$ for $1.5 \mathrm{~min}$ and 25 times at $93^{\circ}$ $\mathrm{C}$ for $5 \mathrm{sec}, 8 \mathrm{sec}$ at $50^{\circ} \mathrm{C}, 72^{\circ} \mathrm{C}$ for $1 \mathrm{~min}$ and final extension at $72^{\circ} \mathrm{C}$ for $10 \mathrm{~min}$. The amplified products $(5$ $\mu \mathrm{l})$ were checked on $1 \%$ agarose gels in TAE buffer. DNA sequencing was performed by CoGenics Genome Express (Meylan, France) using PCR-amplified products as templates.

\section{Sequence Alignment and Phylogenetic Analyses}

We aligned ITS-1, ITS-2 and $16 \mathrm{~S}$ sequences of 50 lymnaeid species and the three outgroups using Prank v. 100311 [43]. Prank is based on an algorithm that can distinguish insertions from deletions and avoid repeated penalization of insertions. Compared to Clustal-W and Muscle, it considerably improves the alignment quality especially in highly variable sequences such as ITSs. Alignments of individual genes were concatenated in a supermatrix with the seqCat.pl v1.0 script [44].

Two different approaches of tree reconstruction, Maximum Likelihood (ML) and Bayesian Inference (BI), were implemented. Analyses were performed by partitioning the supermatrix on the basis of individual loci. ML analyses were conducted using the best-fitting model of sequence evolution. Model selection was based on Akaike's Information Criterion (AIC) using ModelTest 3.7 [45]. ML trees and the corresponding bootstrap supporting values (BP) of the nodes were obtained with PAUP* 4.0b10 [46] using heuristic search with neighbor-joining starting tree, tree bissection-reconnection swapping and 100 bootstrap replicates. BI analyses were performed with MrBayes 3.2 [47]. The tree space was explored using Markov Chain Monte Carlo (MCMC) analyses with random starting trees, five simultaneous, sequentially heated independent chains sampled every 500 trees during five million generations. Suboptimal trees were discarded once the "burn-in" phase was identified and a majority-rule consensus tree, with posterior probability support of nodes (PP), was constructed with the remaining trees.

\section{Susceptibility to Infection by Fasciola hepatica and $F$.} gigantica, and the Evolution of the Chromosome Number in Lymnaeidae

We searched available information on susceptibility to infection by $F$. hepatica and F. gigantica, derived from either analyses of natural populations or from experimental infections, in all species considered using the ISI Web of Science (Thompson-Reuters). We recorded the susceptible or not susceptible status for each species (Table 3). In addition, the haploid number of chromosomes $(\mathrm{n})$ was obtained from previous publications $[7,11,31,48]$.

\section{Results}

\section{A Comprehensive Phylogeny of Lymnaeidae}

The ML and BI trees inferred with the alignment of the supermatrix including 50 Lymnaeidae species and three outgroups (5054 aligned sites) were extremely similar, although some node supports varied between the two approaches. The best model describing the evolution of the supermatrix was $\mathrm{TVM}+\mathrm{I}+\mathrm{G}$ (proportion of invariable sites $=0.2298$; shape parameter $=0.8159)$. Overall, the clades obtained here are consistent with previous results $[7-9,18,39,41]$. Three deeply-rooted clades (hereafter $\mathrm{C} 1, \mathrm{C} 2$ and $\mathrm{C} 3$ ) were detected, basically matching the geographic origin of species (Figure 1 ). The $\mathrm{C} 1$ clade $(\mathrm{n}=18)$ included all American species and two

Table 2 Sets of primers used in PCR amplifications

\begin{tabular}{lllll}
\hline Locus & Forward Primer & Sequence $\mathbf{5}^{\prime} \mathbf{>} \mathbf{3}^{\prime}$ & Reverse Primer & Sequence $\mathbf{5}^{\prime} \mathbf{>} \mathbf{3}^{\prime}$ \\
\hline ITS-1 & Lym1657 & CTGCCCTITGTACACACCG & ITS1-Rixo & TGGCTGCGTTCTTCATCG \\
ITS-2 & News2 & TGTGTCGATGAAGAACGCAG & ITS2-Rixo & TTCTATGCTTAAATTCAGGGG \\
$16 \mathrm{~S}$ & 16F & CGCCTGTTATCAAAAACAT & 16R & CCGGTCTGAACTCAGATCACGT \\
\hline
\end{tabular}


Table 3 Reports of natural or experimental infection of lymnaeids with Fasciola hepatica or F. gigantica

\begin{tabular}{|c|c|c|c|}
\hline Intermediate host & Infection by $F$. hepatica & Infection by $F$. gigantica & Refractory to infection \\
\hline Austropeplea tomentosa & {$[68]$} & & \\
\hline Austropeplea (Lymnaea) viridis & [69] & [9] & \\
\hline Austropeplea ollula & [9] & [9] & \\
\hline Fossaria bulimoides & [70] & & \\
\hline Galba truncatula & [71] & [9] & \\
\hline Lymnaea cousini & {$[72]$} & & \\
\hline Lymnaea (Bakerilymnaea) cubensis & [73] & & \\
\hline Lymnaea diaphana & [9] & & \\
\hline Lymnaea fuscus & [74] & & \\
\hline Lymnaea humilis & {$[75]$} & & \\
\hline Lymnaea (Radix) natalensis & {$[76]$} & {$[9]$} & \\
\hline Lymnaea neotropica & [77] & & \\
\hline Lymnaea (Catascopia) occulta & [9] & & \\
\hline Lymnaea (Stagnicola) palustris & [71] & & \\
\hline Lymnaea sp. from Colombia & [53] & & \\
\hline Lymnaea stagnalis & [78] & & \\
\hline Stagnicola turricola & [9] & & \\
\hline \multicolumn{4}{|l|}{ (= Lymnaea palustris turricola) } \\
\hline Lymnaea viatrix & [79] & & \\
\hline Omphiscola glabra & [71] & & \\
\hline Pseudosuccinea columella & [73] & [9] & {$[80]$} \\
\hline Radix peregra & [71] & [9] & \\
\hline Radix auricularia & {$[76]$} & {$[81]$} & \\
\hline Radix ovata & {$[82]$} & & \\
\hline Radix labiata & {$[83]$} & & \\
\hline Radix lagotis & {$[76]$} & & \\
\hline Radix luteola & & [9] & \\
\hline Radix rubiginosa & {$[76]$} & [9] & \\
\hline Stagnicola caperata & {$[84]$} & & \\
\hline Stagnicola elodes & & & [73] \\
\hline
\end{tabular}

species thought to originate from Europe (Galba truncatula and Lymnaea occulta = Catascopia occulta), although the inclusion of Pseudosuccinea columella was only weakly supported (0.18 BP and $0.30 \mathrm{PP})$. Two highly supported subclades can be recognized within this clade. The first one ( $\mathrm{Cla}$ ) included the South American L. diaphana, the North American Stagnicola caperata, the European L. occulta (= C. occulta), and all other North American Stagnicola. The second subclade (C1b) grouped the South American L. cousini with the North American Fossaria obrussa and L. humilis, on the one hand, and the European G. truncatula, Neotropical L. cubensis (= Bakerilymnaea cubensis), L. neotropica and L. viatrix, the North American F. bulimoides and Lymnaea sp. from Colombia, on the other hand.

The C2 clade $(n=18)$ consisted of exclusively Eurasian species. In this clade, Omphiscola glabra (a smallshelled, morphologically distinct species) first diverged from all other species, including most large-bodied species found in Europe (excluding Radix spp.). This was followed by divergence of L. stagnalis, L. corvus (= S. corvus), L. fuscus, Stagnicola sp. EEAR-Ukraine-2002, L. palustris (= S. palustris) and S. turricola (= L. palustris turricola). These relationships are identical to those reported in $[7,8,18]$.

The C3 clade contained all Australasian and Radix species, including the African Lymnaea (Radix) natalensis. ML and BI analyses indicated that there were two subclades within C3. The first one (C3a) was formed by Austropeplea lessoni and Bullastra cumingiana $(\mathrm{n}=16)$, A. tomentosa and Kutikina hispidina $(\mathrm{n}=16)$, and a subclade grouping $A$. ollula and $A$. viridis (= L. viridis) ( $\mathrm{n}=16)$, on the one hand; and Lymnaea sp. EEARChina-2002 and Lymnaea sp. EEAR-Hawaii-2002 ( $\mathrm{n}=$ 18 according to [48] and [11]; $\mathrm{n}=16$ according to [7]), on the other hand. The second subclade (C3b) consisted of all Radix species $(\mathrm{n}=17)$, including $L$. $(R$.) natalensis, and included two monophyletic groups. The first one was formed by Radix labiata sister to $R$. peregra, $R$. ampla and $R$. lagotis. Note that our samples of 
$R$. peregra from Southern France clustered within the MOTU2 clade described in [26] with no ambiguity, based on analyses of COI and ITS-1 sequences (results not shown). The second, more recently derived clade, was formed by $R$. auricularia and $R$. ovata which were sister to a clade comprising Radix sp. EEAR-Philippines2002, Radix sp. EEAR-Canada-2002 and Radix sp. EEAR-Romania-2002, L. (R.) natalensis sister to $R$. luteola, and $R$. quadrasi sister to R. rubiginosa.

\section{Discussion}

\section{A Comprehensive Phylogeny of Lymnaeidae}

Recent studies have suggested that the Lymnaeidae contains approximately 100 species [1,2], meaning that our phylogeny represents approximately half the existing diversity of the family. The tree presented in Figure 1 indicates that species cluster by geographic origin in three deep clades. One is almost entirely composed of American species, while the two others are from the Old World. The split between the American C1 clade and Old World C2 clade probably dates back to the opening of the Atlantic Ocean 160-130 million years ago (Mya). This date is reasonable given the fossil record suggests the divergence of Physidae-Lymnaeidae took place near the Jurassic period ( 200-145 Mya; [49]).

Concerning the American clade $(\mathrm{C} 1)$ various aspects should be highlighted. Our study is the first to include L. diaphana in a phylogenetic analysis and suggests that this species is sister to the North American Stagnicola and L. occulta ( $=$ C. occulta) (clade C1a), although with low support (0.54 BP and 0.71 PP). Baker [50] reported L. diaphana in South Dakota, consistent with a possible North American origin. However, the species was originally described from southern South America (Strait of Magellan, Chile; [51]) and is currently found in Argentina, Brazil, Chile, Peru and Uruguay. It could be either that the current distribution of $L$. diaphana in South America is not representative of its North American origin or that the ancestor of clade C1a was originally from South America and then migrated northwards, where it gave origin to the Stagnicola of clade C1a. A further point is that L. occulta $(=$ C. occulta) from Poland is unambiguously grouped with this clade and agrees with [41]. This is unexpected as this species is thought to originate from Europe, and was formerly grouped, on the basis of anatomical characters, together with the European L. palustris (=S. palustris) and $S$. turricola $(=$ L. palustris turricola), which appear, as expected, in a predominantly European clade (C2). We hypothesize that $L$. occulta was actually introduced in Europe from North American populations (see below). Finally, our results do not contradict the hypothesis that S. emarginata, S. elodes and S. catascopium are conspecifics, as suggested by [6] and [18]. If this is true, Stagnicola sp. EEAR-Manitoba-2002 should also be synonymized with these three taxa.

Species with similar shell morphology (G. truncatulalike) in the C1b clade cluster together. The only exception is $L$. cousini which clearly belongs to this clade (with maximal BP and PP values) but is morphologically different from all other species in terms of both shell morphology and the anatomy of reproductive organs. Its phylogenetic position suggests the ancestor of clade C1b had a G. truncatula-like morphology and the L. cousini morphology is a derived character. The inclusion of G. truncatula within this clade is unambiguous and agrees with previous results [10]. This species has always been considered a native from the Old World, occurring in Europe, Russia, and North Africa, and to have been recently introduced to South America [32,52]. Our phylogeny suggests that $G$. truncatula represents a branch of an American clade that reached the Old World, where it has evolved and diverged from its American sister species (see below). Interestingly, Lymnaea sp. from Colombia, previously described as G. truncatula [53], was unambiguously identified as a distinct taxonomic entity, yet to be sequenced. We currently lack sequences and population-genetic studies of several taxa described in North America presenting morphological similarities with Lymnaea sp. Therefore, we are not in position to ascertain that this is a new species and to determine whether it is endemic or has been introduced to South America. Thus, we refrain from describing this entity as a new species to avoid adding more noise to the already confusing systematics of the Lymnaeidae.

The second deep clade (C2) consists exclusively of Eurasian species, and species branching agrees [7] and [18]. It does not contradict the hypothesis that L. palustris (= S. palustris) and S. turricola (= L. palustris turricola) are synonymous, as proposed by [18]. These two taxa indeed only differ by two anatomical characters (preputium length to penis length ratio, and the relative length of the distal part of the prostate) [54].

The third deep clade (C3) includes all species inhabiting Australia and the Indo-Pacific region, as well as Radix species. According to this tree, Austropeplea is a polyphyletic genus, in agreement with results obtained by [6], [7] and [11]. Remigio [7] suggested monophyly of Autropeplea spp., Bullastra cumingiana, Lymnaea sp. EEAR-China-2002 and Lymnaea sp. EEAR-Hawaii-2002. Our results indicate that Kutikina hispida and Lymnaea gen. sp. from Hawaii are also members of this clade. On the other hand, Radix seems to be a monophyletic genus, in agreement with [8], [11], [18] and [26], but in contradiction with results of [6] and [7]. Importantly, $L$. $(R$.) natalensis, the only known endemic African species, branched unambiguously within the Radix clade, in 
Bulinus forskalii

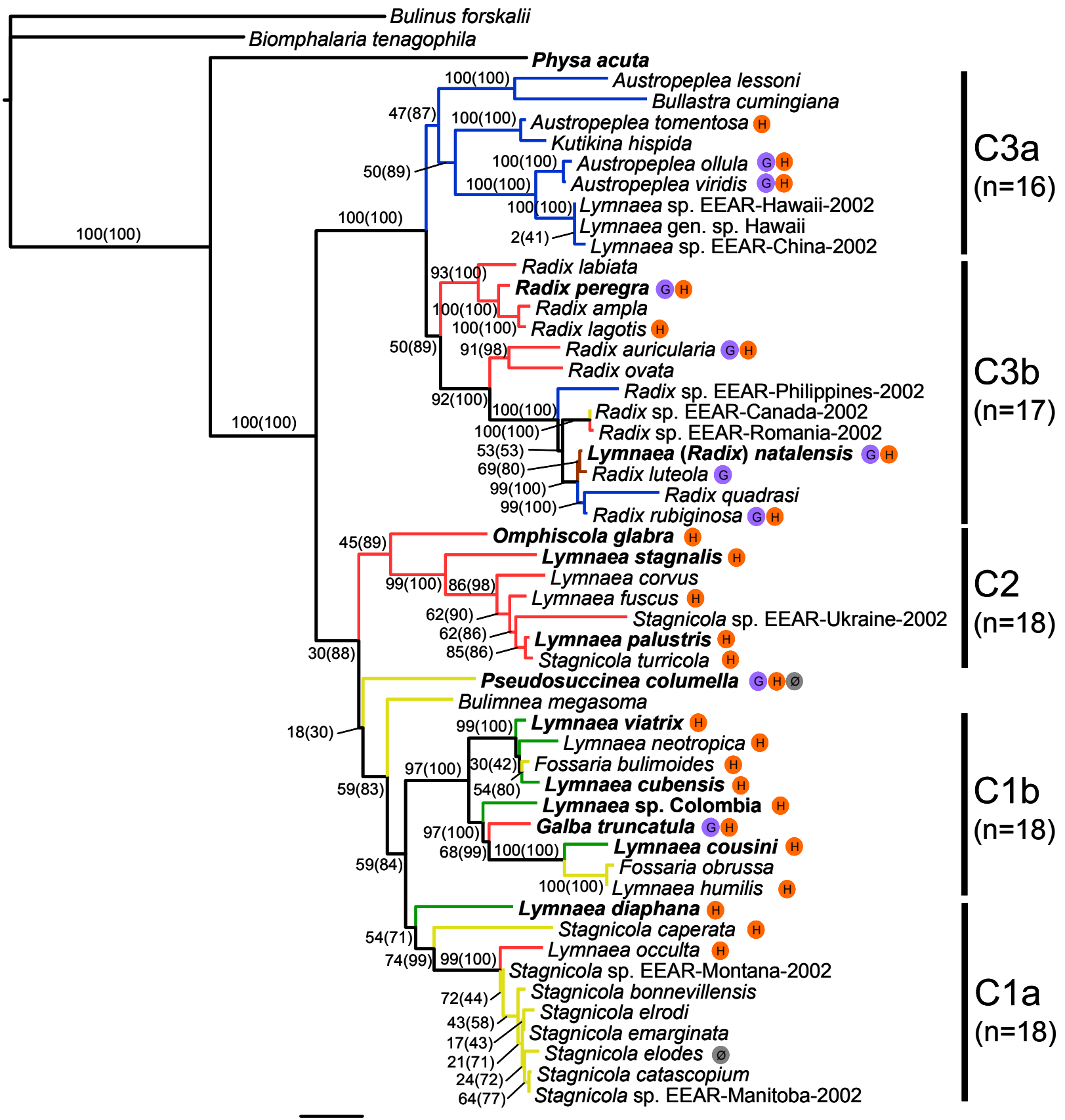

0.05

Figure 1 Phylogeny of the Lymnaeidae. The tree was obtained by concatenating the 16 S, ITS-1 and ITS-2 sequences, and includes 50 species and three outgroups. Colored branches represent geographic origin; blue = Australasian; red = Eurasia; brown = Africa and Indic ocean; ochre = North America; green = Central and South America. Species naturally or experimentally serving as intermediate hosts of Fasciola hepatica (H),

F. gigantica $(G)$ or refractory to infection $(\varnothing)$ are shown. $(n)$ is the haploid number of chromosomes. Values on nodes represent bootstrap percentages (BP) and posterior probabilities (PP; given within parentheses). Species sequenced by us are in bold characters.

agreement with [39], sister to R. luteola from Sri Lanka. This result confirms that the name Radix natalensis better reflects its phyletic relationships than does Lymnaea natalensis. Our results do not support the hypothesis that $R$. peregra and $R$. ovata are synonymous [18]. Their synonymy is indeed still a controversial matter $[26,38,55]$. Alternatively, $R$. peregra, $R$. ampla and $R$. lagotis are closely related taxa, in agreement with [18], and might potentially be conspecifics, although confirmation using mating experiments seems necessary. 
In summary (and ignoring recent introductions) we have three old centers of diversification in the Lymnaeidae family: America, Eurasia and the Indo-Pacific region. In the latter, the Radix clade diversified and then expanded towards Eurasia and Africa. This is also true of G. truncatula, a branch of the American clade that invaded the Old World. In general, the Lymnaeidae morphology has evolved slowly and most species within clades are similar: small-shelled turriform, G. truncatula-like in the American clade; large and high-spired shells in the Eurasian Lymnaea; and large, rounded or ovate shells in the Indo-Pacific clade, especially in Radix. A few branches, including O. glabra, and L. cousini, have evolved distinctive morphologies that differ from all other lymnaeids. Note, however, that limpetshaped species (e.g., $\operatorname{Lan} x)$ were not analyzed here, and it is not possible to discuss their phylogenetic position and morphological evolution. If they constitute a separate clade, say $\mathrm{C} 4$, our hypothesis of slow morphological evolution would be valid.

Concerning chromosome numbers, [31] and [56] hypothesized that evolution in Lymnaeidae proceeded from low $(\mathrm{n}=16)$ to high $(\mathrm{n}=17$ and 18$)$ values. Accordingly, Austropeplea with 16 chromosome pairs was thought to be the most "primitive" form, followed by Radix with 17 pairs and Stagnicola with 18 pairs. Our molecular phylogeny contradicts this idea. The ancestral state in Lymnaeidae seems to be $\mathrm{n}=18$, as it is in other Basommatophoran gastropods (Chilinidae, Lancinae, Latiidae, Planorbidae and Physidae) [57]. Eighteen pairs of chromosomes is likely to be a pleisomorphic character, in agreement with [6] and [7], and thus species of clades C3a $(n=16)$ and C3b $(n=17)$ would represent derived rather than ancestral states. Remigio [7] suggested that $\mathrm{n}=16$ evolved from $\mathrm{n}=17$. Our results do not contradict this idea, although it is difficult to infer the number of chromosomes for the ancestor of clade C3. In addition, if Lymnaea spp. from Hawaii and China have indeed 18 chromosome pairs, as suggested by [11], either a reversion from $n=16$ to $n=$ 18 or three independent evolutions to $n=16$ would be required (Figure 1).

\section{Nomenclature in Lymnaeidae}

The nomenclature of genera has been one of the most confusing issues in the Lymnaeidae systematics. Most genus names are not fixed and are based more on phenotypic resemblances than on sound evolutionary and phylogenetic considerations. For instance, a single genus was recognized by [58], two by [12], and up to 34 genera by others [13,59-62]. Our results indicate that genera in Lymnaeidae do not reflect phylogenetic relationships, to the notable exception of Radix (including $L$. (R.) natalensis).
The type species of Lymnaea is L. stagnalis Linnaeus, 1758; the type species of Stagnicola Jeffreys, 1830 is S. palustris (=L. palustris); and the type species of Omphiscola Rafinesque, 1819 is O. glabra. However, it is clear from our results that these three species belong to the same clade (C2) and that Lymnaea is not a monophyletic group. We propose that species of clade C2 should all be called Lymnaea, according to the principle of priority of the International Code of Zoological Nomenclature (ICZN). By extension, Stagnicola should not be used to name species in clade Cla since the type species belongs to clade $\mathrm{C} 2$. Meier-Brook and Bargues [63] suggested including S. emarginata, S. elodes, S. catascopium and L. occulta within a new genus Catascopium, while $S$. caperata would belong to the genus Hinkleyia Baker, 1928 [8]. Our phylogeny does not conflict with this nomenclature, although it would seem preferable to identify all species of clade $\mathrm{Cla}$ with the same name to reflect the close evolutionary relationships among these species. Hinkleyia would be the preferable name according to the ICZN. On the other hand, at least four genera names have been used for species of clade C1b: Lymnaea Lamarck, 1799; Galba Schrank, 1803; Fossaria Westerlund, 1885; and Bakerilymnaea. In the light of the present results, it would be preferable to unify nomenclature. According to the ICZN, Lymnaea should be the unified name, but given that the type species belongs to clade $\mathrm{C} 2$, Galba could be a more appropriate name. Finally, as said above, Austropeplea Cotton, 1942 is not a monophyletic group, and employing the genus Kutikina Ponder and Waterhouse, 1997 (one species: K. hispida) seems unjustified on the basis of the current phylogeny. This would also be consistent with results of [11]. It would be preferable to use Bullastra Pfeiffer, 1839 for all species of clade C3a to fit the ICZN.

\section{Unravelling Biological Invasions of Lymnaeidae using the Phylogeny}

Although the Lymnaeidae phylogeny presented in Figure 1 matches reasonably well with the geographical origin of samples, some species clustered in clades with different geographic origins stand out and potentially correspond to biological invasions of a more or less recent origin. From an epidemiological standpoint, this is a key issue because some lymnaeid species are more susceptible than others to trematode infection, hence biological invasions can help explain the broad geographic distribution of fascioliasis and in determining the risks for veterinary and public health (see e.g. [64]).

First, one of our most puzzling results concerns the origin of G. truncatula Müller, 1774, the main vector of fascioliasis in the Old World. The idea that this species is native to Europe, as it was described from Germany, 
is widely accepted [65]. However, a very different picture emerges from our phylogeny: it is the only European species branching with the wholly American clade C1b. This strongly suggests that America is where G. truncatula originated. This is consistent with its detection in Alaska and the Yukon territory [50]. It is possible the current distribution of G. truncatula in North America is broader, but has remained cryptic because it has been confounded with other taxa. Indeed, Hubendick noted that, "it is a matter of some doubt whether Lymnaea humilis in North America is a distinct species or is specifically connected to L. truncatula" (= G. truncatula) [66]. It could be that some populations of L. humilis in reality correspond to G. truncatula. At least 10 species of Lymnaeidae from North America placed in synonymy of $L$. humilis by [12], but considered as valid by [13], present conchological similarities with G. truncatula: L. galbana Say, 1825; L. modicella Say, 1825; L. obrussa Say, 1825; L. parva Lea, 1841; L. exigua Lea, 1841; L. rustica Lea, 1841; L. tazevelliana Wolf, 1869; L. dalli Baker, 1906; L. cyclostoma Walker, 1908; and L. peninsulae Walker, 1908. Unfortunately, neither detailed anatomical descriptions nor molecular data are available in any of these taxa. Sampling and sequencing of morphologically similar North American taxa could shed light on this question.

Second, as mentioned above, $L$. occulta $(=C$. occulta) is the only species from Europe clustering within clade $\mathrm{C} 2$ and seems to correspond to a passage from North America to Europe. As stated by [8] (and references therein), L. occulta is distributed in eastern Germany, Poland, the former Czechoslovakia, the former Yugoslavia, Ukraine, Sweden, and some rivers in the delta of Lake Baikal. It is hypothesized that the species could reach the far east Asia where it could have been confounded with other stagnicoline species because of similarity in shell morphology [12]. In any case, it seems clear that L. occulta has its origins in America.

Finally, the two Radix sp. are likely introductions originating from the Indo-Pacific area to Canada and Romania. The fact that these two sister taxa (potentially the same species) are found in distant geographic locations is indicative of recent introductions.

\section{The Relationships between Lymnaeidae and Fasciola hepatica and F. gigantica}

From an epidemiological standpoint, digenetic trematodes show marked specificity for their intermediate hosts but can infect a broad spectrum of definite hosts. Usually, species are oioxenous (one parasite species: one snail species) or stenoxenous (one parasite species: a few, closely related snail species) [67]. This is because when the infectious form of the parasite (the miracidium) enters a snail, it must encounter an internal physiological and biochemical environment that supports its complete development. However, the case of $F$. hepatica seems to be different. Our results show that lymnaeid species serving as intermediate hosts of this trematode are widely distributed across the phylogeny (Figure 1). Basically, all clades contain species that have proven to be naturally or experimentally infected with this parasite. Only a few species have been shown to be resistant to infection (Table 3 ). In contrast, species involved in F. gigantica transmission are more clustered in the phylogeny (Figure 1). Although not all species are equally susceptible to infection by $F$. hepatica, the broad capacity of this parasite to infect phylogenetically distant species is remarkable. The Lymnaeidae-Fasciola system differs from the well known Planorbidae-Schistosoma system, in which each trematode species infects a narrow group of hosts that share a close phylogenetic relationship [4]. The behavior of $F$. hepatica with respect to Lymnaeidae is of paramount importance in epidemiology control programs: rather than focusing on a single, or a handful of snail species, fascioliasis control programs should cover a broader spectrum of intermediate hosts that inhabit diverse habitats and ecological conditions. Our results confirm that the presence of F. hepatica in all continents is strongly favored by its capacity to infect local lymnaeids. Based on these results, it seems that all geographic regions in the world are exposed to the epidemiological risk of fascioliasis.

\section{Conclusion}

At least four conclusions can be drawn from this study. First, combining information from different genes (supermatrix) is a robust approach to reconstruct the evolutionary history of the Lymnaeidae. Our results indicate that members of this family diverged in three deeply-rooted clades corresponding to the geographic origin of species (America, Eurasia and the Indo-Pacific region). Our phylogeny allowed us to pinpoint discordances between ancestral and current geographic distributions of some species, potentially indicating more or less recent biological invasions. Transfers from America to Eurasia are suggested for G. truncatula and L. occulta $(=$ C. occulta $)$, as well as passages from the Indo-Pacific to Europe and North America for Radix sp. However, sampling and sequencing efforts remain to be done especially in the Palaearctic and Nearctic regions in which the family diversity is thought to be the largest. This would help resolve the weakly supported relationships (e.g., P. columella), determine the pace of morphological evolution, establish taxonomic synonymy, and determine the phylogenetic relevance of poorly known genera (e.g., Acella, Lantzia, Lanx and Myxas). Second, with the exception of Radix (including the African $L$. (R.) natalensis), genus names in Lymnaeidae do not 
reflect the phyletic relationships among species. The group taxonomy should be reconsidered to gain some biological meaning. Third, the number of chromosomes in Lymnaeidae has evolved from an ancestral state of 18 pairs to a derived 17 and 16 pairs. Finally, while the intermediate hosts of $F$. gigantica are basically restricted to clade C3, F. hepatica is able to infect species from all main clades (C1, C2 and C3). This suggests that the cosmopolitan distribution of $F$. hepatica is largely favored by its capacity to infect local lymnaeids, and highlights the importance of the correct identification of intermediate-host species in fascioliasis control programs.

\section{Acknowledgements}

We thank E. J. P. Douzery, S. Glémin and I. D. Vélez for helpful discussions, and P. Agnew and two anonymous reviewers for constructive comments that improved the quality of the paper. ACC was supported by a grant of the Département de Soutien et Formation of the IRD, and SHB by the Université Montpellier 2. This study was supported by the Cytrix INSU program, CNRS and IRD.

\section{Author details}

${ }^{1}$ Laboratoire Génétique et Evolution des Maladies Infectieuses, UMR 2724 CNRS-IRD, IRD 911 avenue Agropolis, BP64501, 34394 Montpellier Cedex 5, France. ${ }^{2}$ Institut des Sciences de l'Evolution UMR 5554, Université Montpellier II, Place Eugène Bataillon, 34095 Montpellier Cedex 5, France. ${ }^{3}$ Centre d'Ecologie Fonctionnelle et Evolutive UMR 5175, 1919 Route de Mende, Campus CNRS, 34293 Montpellier Cedex 5, France. ${ }^{4}$ USR 3278 CNRS-EPHE, CRIOBE Université de Perpignan, 68860 Perpignan-Cedex, France. ${ }^{5}$ Département de Biologie-Ecologie (Faculté des Sciences) cc- 046- Université Montpellier 2, 4 Place Eugène Bataillon, 34095 Montpellier Cedex 5, France.

\section{Authors' contributions}

ACC and SHB designed the study. ACC, JSE, PDavid, PJ and JPP sampled snails. ACC and PDurand carried out experiments. ACC and JSE performed analyses. All authors discussed the results and wrote the paper.

Received: 16 June 2010 Accepted: 9 December 2010 Published: 9 December 2010

\section{References}

1. Jarne P, Pointier JP, David P, Koene JM: Basommatophoran Gastropods. In The Evolution of "Primary" Sexual Characters in Animals. Edited by: CórdobaAguilar A, Leonard JL. New York, USA: Oxford University Press, Inc; 2010:

2. Strong EE, Gargominy O, Ponder WF, Bouchet P: Global diversity of gastropods (Gastropoda; Mollusca) in freshwater. Hydrobiologia 2008, 595:149-166.

3. DeJong RJ, Morgan JAT, Paraense WL, Pointier JP, Amarista M, AyehKumi PFK, Babiker A, Barbosa CS, Brémond P, Canese AP, et al: Evolutionary relationships and biogeography of Biomphalaria (Gastropoda: Planorbidae) with implications regarding its role as host of the human bloodfluke, Schistosoma mansoni. Molecular Biology and Evolution 2001, 18(12):2225-2239.

4. Morgan JAT, DeJong RJ, Jung Y, Khallaayoune K, Kock S, Mkoji GM, Loker ES: A phylogeny of planorbid snails, with implications for the evolution of Schistosoma parasites. Molecular Phylogenetics and Evolution 2002, 25:477-488.

5. Wethington AR, Lydeard C: A molecular phylogeny of Physidae (Gastropoda: Basommatophora) based on mitochondrial DNA sequences. Journal of Molluscan Studies 2007, 73:241-257.

6. Remigio EA, Blair D: Molecular systematics of the freshwater snail (Pulmonata: Basommatophora) utilising mitochondrial ribosomal DNA sequences. Journal of Molluscan Studies 1997, 63:173-185.

7. Remigio EA: Molecular phylogenetic relationships in the aquatic snail genus Lymnaea, the intermediate host of the causative agent of fascioliasis: insights from broader taxon sampling. Parasitology Research 2002, 88:687-696.

8. Bargues MD, Horák P, Patzner RA, Pointier JP, Jackiewicz M, Meier-Brook C, Mas-Coma S: Insights into the relationships of paleartic and neartic Lymnaeids (Mollusca: Gastropoda) by rDNA ITS-2 sequencing and phylogeny of Stagnicoline intermediate host species of Fasciola hepatica. Parasite 2003, 10:243-255.

9. Bargues MD, Mas-Coma S: Reviewing lymnaeid vectors of fascioliasis by ribosomal DNA sequence analyses. Journal of Helminthology 2005, 79:257-267.

10. Bargues MD, Artigas P, Mera y Sierra RL, Pointier JP, Mas-Coma S: Characterisation of Lymnaea cubensis, L. viatrix and L. neotropica n. sp., the main vectors of Fasciola hepatica in Latin America, by analysis of their ribosomal and mitochondrial DNA. Annals of Tropical Medicine \& Parasitology 2007, 101(7):621-641.

11. Puslednik L, Ponder WF, Dowton M, Davis AR: Examining the phylogeny of the Australasian Lymnaeidae (Heterobranchia: Pulmonata: Gastropoda) using mitochondrial, nuclear and morphological markers. Molecular Phylogenetics and Evolution 2009, 52:643-659.

12. Hubendick B: Recent Lymnaeidae, their variation, morphology, taxonomy, nomenclature and distribution. Kungl Svenska Vetenskapsakademiens Handlingar 1951, 3:1-223.

13. Burch JB: North American freshwater snails. Transactions of the POETS Society 1982, 1(4):217-365.

14. Brown DS: Freshwater Snails of Africa and their Medical Importance. London, U.K.: Taylor and Francis Ltd;" Second 1994.

15. Hillyer GV, Apt W: Food-borne trematode infections in the Americas. Parasitology Today 1997, 13:87-88.

16. Kaplan RM: Fasciola hepatica: A review of the economic impact in cattle and considerations for control. Veterinary Therapeutics 2001, 2(1):40-50.

17. Dawes B: The Trematoda with Special Reference to British and other European Forms. London: Cambridge University Press; Second 1968.

18. Bargues MD, Vigo M, Horak P, Dvorak J, Patzner RA, Pointier JP, Jackiewicz M, Meier-Brook C, Mas-Coma S: European Lymnaeidae (Mollusca: Gastropoda), intermediate hosts of trematodiases, based on nuclear ribosomal DNA ITS-2 sequences. Infection, Genetics and Evolution 2001, 1:85-107.

19. Graczyk T, Fried B: Echinostomiasis: a common but forgotten food-borne disease. American Journal of Tropical Medicine and Hygiene 1998, 58:501-504.

20. Horák JG, Kolárová L: Bird: schistosomes: do they die in mammalian skin? Trends in Parasitology 2001, 17:66-69.

21. Degueurce F, Abrous M, Dreyfuss G, Rondelaud D, J. G: Paramphistomum daubneyi and Fasciola hepatica: the prevalence of natural or experimental infections in four species of freshwater snails in eastern France. Journal of Helminthology 1999, 73:197-202.

22. Gayo V, Mera y Sierra R: With IAEA support, Latin America controls liver fluke (Fasciola hepatica) in livestock and humans. FAO/IAEA program 2010 [http://www-naweb.iaea.org/nafa/aph/stories/2010-fasciola-project.html].

23. Torgerson P, Claxton J: Epidemiology and control. In Fasciolosis. Edited by: Dalton JP. CAB International, Oxon; 1999:113-149.

24. Hurtrez-Boussès $S$, Meunier $C$, Durand P, Renaud F: Dynamics of hostparasite interactions: the example of population biology of the liver fluke (Fasciola hepatica). Microbes and Infection 2001, 3:841-849.

25. Hurtrez-Boussès $S$, Pendino A, Bernabé C, Rondelaud D, Durand C, Meunier C, Hurtrez-Boussès J-E, Renaud F: Comparison between shell morphology and genetic diversity in two sympatric lymnaeid snails, vectors of fasciolosis. Canadian Journal of Zoology 2005, 83:1643-1648.

26. Pfenninger $M$, Cordellier M, Streit B: Comparing the efficacy of morphologic and DNA-based taxonomy in the freshwater gastropod genus Radix (Basommatophora, Pulmonata). BMC Evolutionary Biology 2006, 6(100):1-14.

27. Paraense WL: Lymnaea viatrix: a study of topotypic specimens (Mollusca: Lymnaeidae). Revista Brasileira de Biologia 1976, 36:419-428.

28. Pointier JP, Cazzaniga NJ, González-Salas C, Gutiérrez A, Arenas JA, Bargues MD, Mas-Coma S: Anatomical studies of sibling species within Neotropical lymnaeids, snail intermediate hosts of fascioliasis. Memórias do Insttituto Oswaldo Cruz 2006, 101(4):431-435.

29. Burch JB, Lindsay GK: An inmmunological approach to lymnaied systematics. American Malacological Union 1968, 34:22-23. 
30. Burch JB: Chromosome studies of aquatic pulmonate snails. The nucleus 1960, 3(2):177-208

31. Inaba A: Cytotaxonomic studies of Lymnaeid snails. Malacologia 1969, 7(2-3):143-168.

32. Jabbour-Zahab R, Pointier JP, Jourdane J, Jarne P, Oviedo JA, Bargues MD, Mas-Coma S, Anglés R, Perera G, Balzan C, et al: Phylogeography and genetic divergence of some lymnaeid snails, intermediate hosts of human and animal fascioliasis with special reference to lymnaeids from the Bolivian Altiplano. Acta Tropica 1997, 64:191-203.

33. Durand P, Pointier JP, Escoubeyrou K, Arenas JA, Yong M, Amarista M, Bargues MD, Mas-Coma S, Renaud F: Occurrence of a sibling species complex within neotropical lymnaeids, snail intermediate hosts of fascioliasis. Acta Tropica 2002, 83:233-240

34. Ward PL, Goater CP, Mikos M: Shell variation in sympatric freshwater Lymnaea peregra and L. ovata (Gastropoda: Lymnaeidae). Biological Journal of the Linnean Society 1997, 61:139-149.

35. Arthur W: Control of shell shape in Lymnaea stagnalis. Heredity 1982, 49:153-161.

36. Lam PKS, Calow P: Differences in the shell shape of Lymnaea peregra (Müller) (Gastropoda: Pulmonata) from lotic and lentic habitats; environmental or genetic variance? Journal of Molluscan Studies 1988, 54:197-207.

37. Evans NJ: Biochemical variation and shell shape in populations of the freshwater snail Lymnaea peregra (Mollusca: Gastropoda, Pulmonata) from south-west Ireland. Biological Journal of the Linnean Society 1989, 36:65-78.

38. Wullschleger EB, Jokela J: Morphological plasticity and divergence in lifehistory traits between two closely related freshwater snails, Lymnaea ovata and Lymnaea peregra. Journal of Molluscan Studies 2002, 68(1):1-5.

39. Albrecht C, Wolff C, Glöer P, Wilke T: Concurrent evolution of ancient sister lakes and sister species: the freshwater gastropod genus Radix in lakes Ohrid and Prespa. Hydrobiologia 2008, 615:157-167.

40. Mas-Coma S, Esteban JG, Bargues MD: Epidemiology of human fascioliasis: a review and proposed new classification. Bulletin of the World Health Organization 1999, 77(4):340-346.

41. Bargues MD, Artigas $P$, Jackiewicz M, Pointier JP, Mas-Coma S: Ribosomal DNA ITS-1 sequence analysis of European Stagnicoline Lymnaeidae (Gastropoda). Heldia 2004, 6:57-68.

42. Almeyda-Artigas RJ, Bargues MD, Mas-Coma S: ITS-2 rDNA sequencing of Gnathostoma species (Nematoda) and elucidation of the species causing human gnathostomiasis in the Americas. Journal of Parasitology 2001, 86:537-544.

43. Löytynoja A, Goldman N: An algorithm for progressive multiple alignment of sequences with insertions. Proceedings of the National Academy of Sciences USA 2005, 102(30):10557-10562.

44. Bininda-Emonds ORP: seqCat.pl v1.0. Program distributed by the author. AG Systematik und Evolutions biologie, IBU - Fakultät V, Carl von Ossietzky Universität Oldenburg; 2005.

45. Posada D, Crandall KA: Modeltest: testing the model of DNA substitution. Bioinformatics 1998, 14:817-818.

46. Swofford DL: PAUP*. Phylogenetic Analysis Using Parsimony (*and Other Methods). Sinauer Associates, Sunderland MA (Program) 2002.

47. Huelsenbeck JP, Ronquist F: MrBayes: Bayesian inference of phylogenetic trees. Bioinformatics 2001, 17:754-755.

48. Burch JB: Chromosome numbers of Hawaiian Lymnaeidae. Malacological Review 1971, 4:209-210.

49. Taylor DW: Aspects of freshwater mollusc ecological biogeography. Palaeogeography, Palaeoclimatology, Palaeoecology 1988, 62:511-576.

50. Baker FC: The Lymnaeidae of North and Middle America, recent and fossil. vol. Special Publication No. 3 Chicago: Chicago Academy of Sciences; 1911.

51. King PP: Description of Cirrhipeda, Conchifera and Mollusca, in a collection formed by the Officers of H.M.S. Adventure and Beagle employed between the year 1826 and 1830 in surveying the Southern Coasts of South America, including the Straits of Magalhaens and the Coast of Tierra del Fuego. Zoology 1830, 47:332-349.

52. Meunier C, Tirard C, Hurtrez-Boussès S, Durand P, Bargues MD, Mas-Coma S, Pointier JP, Jourdane J, Renaud F: Lack of molluscan host diversity and the transmission of an emerging parasitic disease in Bolivia. Molecular Ecology 2001, 10:1333-1340.
53. López LP, Romero J, Velásquez LE: Aislamiento de Paramphistomidae en vacas de leche y en el hospedador intermediario (Lymnaea truncatula y Lymnaea columella) en una granja del trópico alto en el occidente de Colombia. Revista Colombiana de Ciencias Pecuarias 2008, 21:9-18.

54. Jackiewicz M: Phylogeny and relationship within the European species of the family Lymnaeidae. Folia Malacologica 1993, 5:61-95

55. Wullschleger EB, Wiehn J, Jokela J: Reproductive character displacement between the closely related freshwater snails Lymnaea peregra and $L$. ovata. Evolutionary Ecology Research 2002, 4:247-257.

56. Burch JB: Chromosome number and systematics in Euthyneuran snails. Proceedings First European Malacological Congress: 1962; London 1962.

57. Patterson CM, Burch JB: Chromosomes of pulmonate molluscs. Edited by: Fretter V, Peake J. London: Accademic press; 1978:2A:171-217.

58. Walter HJ: Evolution, taxonomic revolution, and zoogeography of the Lymnaeidae. Bulletin of the American Malacological Union 1968, 34:18-20.

59. Malek EA: Snail hosts of schistosomiasis and other snail-transmitted diseases in tropical America: a manual. Pan America Health Organization, Washington DC; 1985, 325.

60. Burch JB: A guide to the freshwater snails of the Philippines. Malacological Review 1980, 13:121-143.

61. Jackiewicz M: Phylogeny and relationships within the European species of the family Lymnaeidae. Folia Malacologica 1993, 5:61-95.

62. Glöer P, Meier-Brook C: Süsswassermollusken. Bestimmungsschlüssel für die Bundesrepublik Deutschland. 12 edition. Hamburg, Germany: Deutscher Jugendbund für Naturbeobachtung; 1998.

63. Meier-Brook C, Bargues MD: Catascopia, a new genus for three Nearctic and one Palaearctic stagnicoline species (Gastropoda: Lymnaeidae). Folia Malacologica 2002, 10:83-84.

64. Davis MA: Invasion Biology. New York, USA: Oxford University Press, Inc 2009.

65. Rondelaud D, Vignoles $P$, Dreyfuss G: La limnée tronquée. Un mollusque d'intérêt médical et vétérinaire. Limoges, France: Presses Universitaires de Limoges; 2009

66. Dillon R: Freshwater gastropods of North America. The Blog of the FWGNA Project 2008 [http://fwgna.blogspot.com/search/label/Lymnaeidae]

67. Adema CM, Loker ES: Specificity and immunobiology of larval digeneansnail associations. In Advances in Trematode Biology. Edited by: Fried B, Graczyk TK. CRC Press, Boca Raton, FL; 1997:229-253.

68. Whitlock HV, Chow DCM, Kelly JD: The laboratory maintenance of fieldcollected Lymnaea tomentosa for the production of Fasciola hepatica metacercariae. Veterinary Parasitology 1976, 1(4):317-325.

69. Lee CG, Cho SH, Lee CY: Metacercarial production of Lymnaea viridis experimentally infected with Fasciola hepatica. Veterinary Parasitology 1995, 58.

70. Rognlie MC, Dimke KL, Ports RS, Knapp SE: Seasonal transmission of Fasciola hepatica in Montana, USA, with detection of infected intermediate hosts using a DNA-based assay. Veterinary Parasitology 1996, 65:297-305.

71. Sindou P, Cabaret J, Rondelaud D: Survival of snails and characteristic lesions of Fasciola hepatica infection in four European species of Lymnaea. Veterinary Parasitology 1991, 40(1-2):47-58.

72. Villavicencio A, Carvalho de Vasconcellos M: First report of Lymnaea cousini Jousseaume, 1887 naturally infected with Fasciola hepatica (Linnaeus, 1758) (Trematoda: Digenea) in Machachi, Ecuador. Memórias do Instituto Oswaldo Cruz 2005, 100(7):735-737

73. Cruz-Reyes A, Malek EA: Suitability of six lymnaeid snails for infection with Fasciola hepatica. Veterinary Parasitology 1987, 24:203-210.

74. Dreyfuss G, Abrous M, Rondelaud D: The susceptibility of Lymnaea fuscus to experimental infection with Fasciola hepatica. Journal of Parasitology 2000, 86(1):158-160.

75. Cruz-Mendoza I, Figueroa JA, Correa D, Ramos-Martínez E, LecumberriLópez J, Quiroz-Romero H: Dynamics of Fasciola hepatica infection in two species of snails in a rural locality of Mexico. Veterinary Parasitology 2004, 121:87-93

76. Smyth JD: Introduction to Animal Parasitology. Melbourne: Cambridge University Press; "Third 1994.

77. Mera y Sierra R, Artigas P, Cuervo P, Deis E, Sidoti L, Mas-Coma S, Bargues MD: Fascioliasis transmission by Lymnaea neotropica confirmed by nuclear rDNA and mtDNA sequencing in Argentina. Veterinary Parasitology 2009, 166:73-79. 
78. Kendall SB: Lymnaea stagnalis as an intermediate host of Fasciola hepatica. Nature 1949, 163:880-881.

79. Kleiman F, Pietrokovsky S, Prepelitchi L, Carbajo AE, Wisnivesky-Colli C: Dynamics of Fasciola hepatica transmission in the Andean Patagonian valleys, Argentina. Veterinary Parasitology 2007, 145:274-286.

80. Gutiérrez A, Pointier JP, Yong M, Sánchez J, Théron A: Evidence of phenotypic differences between resistant and susceptible isolates of Pseudosuccinea columella (Gastropoda: Lymnaeidae) to Fasciola hepatica (Trematoda: Digenea) in Cuba. Parasitology Research 2003, 90:129-134.

81. Velusamy R, Singh BP, Raina OK: Detection of Fasciola gigantica infection in snails by polymerase chain reaction. Veterinary Parasitology 2004, 120:85-90

82. Vignoles P, Dreyfuss $G$, Rondelaud D: Redial growth and cercarial productivity of Fasciola hepatica in three species of young lymnaeid snails. Journal of Helminthology 2002, 76(3):269-272.

83. Caron Y, Lasri S, Losson B: Fasciola hepatica: An assessment on the vectorial capacity of Radix labiata and $R$. balthica commonly found in Belgium. Veterinary Parasitology 2007, 149:95-103.

84. Knapp SE, Dunkel AM, Han K, Zimmerman LA: Epizootiology of fascioliasis in Montana. Veterinary Parasitology 1992, 42:241-246.

doi:10.1186/1471-2148-10-381

Cite this article as: Correa et al:: Bridging gaps in the molecular phylogeny of the Lymnaeidae (Gastropoda: Pulmonata), vectors of Fascioliasis. BMC Evolutionary Biology 2010 10:381.

\section{Submit your next manuscript to BioMed Central and take full advantage of:}

- Convenient online submission

- Thorough peer review

- No space constraints or color figure charges

- Immediate publication on acceptance

- Inclusion in PubMed, CAS, Scopus and Google Scholar

- Research which is freely available for redistribution

Submit your manuscript at www.biomedcentral.com/submit 